Cyro Albuquerque Neto cyro.albuquerque@poli.usp.br

Jurandir Itizo Yanagihara

Senior Member, ABCM jiy@usp.br

\author{
Fábio Turri \\ fabio.turri@poli.usp.br \\ University of Sao Paulo - USP \\ Escola Politécnica \\ Department of Mechanical Engineering \\ 055809-900 São Paulo, SP, Brazil
}

\section{A Carbon Monoxide Transport Model of the Human Respiratory System Applied to Urban Atmosphere Exposure Analysis}

The aim of this work is to analyze the carbon monoxide (CO) transport in the human body submitted to several physical activity levels. A complete mathematical model of the human respiratory system was developed, considering the exchanges of $\mathrm{CO}$, oxygen (O2) and carbon dioxide (CO2) in the lung, blood and tissues. The human body was divided in the following compartments: alveolar, pulmonary capillaries, arterial, venous, tissue capillary and tissues. The gas transport in the blood and tissues is represented by empirical equations. The physiological parameters were described in function of physical activity. The model was validated by comparing its results with experimental data of controlled CO exposition. The agreement was excellent. CO concentration curves for critical days of São Caetano do Sul city (SP, Brazil) atmosphere were used as model input. The simulation results for some physical activities show that the more intense the activity, the larger the blood carboxyhemoglobin (COHb) level variations. The COHb level was compared with a CO quality air criteria, which showed to be adequate for low and moderate physical activity levels.

Keywords: compartment model, carbon monoxide, gas transport, respiratory system, air pollution

\section{Introduction}

The carbon monoxide (CO) is a colorless, odorless and insipid gas. It has been the main cause of accidental deaths from poisoning. It is responsible for the largest amount of pollutant launched in the atmosphere, produced by man and nature. The main source is the fossil fuel burning (coal, oil and natural gas), mostly produced by motorized vehicles. The human body produces $\mathrm{CO}$ at low levels.

The function of the human respiratory system is to provide oxygen $\left(\mathrm{O}_{2}\right)$ to the tissues and to eliminate the carbon dioxide $\left(\mathrm{CO}_{2}\right)$ produced by them. Most of the $\mathrm{O}_{2}$ transported by the blood is through its reaction with hemoglobin molecules. The transport of CO happens in the same way, but its affinity with hemoglobin is about 250 times higher than $\mathrm{O}_{2}$. The presence of $\mathrm{CO}$ in the blood reduces its capacity to carry $\mathrm{O}_{2}$. Therefore, large $\mathrm{CO}$ concentrations produce the lack of $\mathrm{O}_{2}$ in the tissues. The bond between $\mathrm{CO}$ and hemoglobin is called carboxyhemoglobin $(\mathrm{COHb})$, represented by the amount (\%) of hemoglobin reacted with CO. It is used to relate the CO effects in the human body (Tab. 1). It is measured by blood analysis or exhaled air. In the absence of measurement methods, the $\mathrm{COHb}$ can be estimated through mathematical models.

Most mathematical models are empirical (Forbes, Sargent and Roughton, 1945; Pace et al., 1946; Lilienthal and Pine, 1946). The output of an empirical model has consistency only for the conditions in which the experiment was carried out. More elaborated empirical models were proposed by Peterson and Stewart (1970) and Stewart et al. (1973) for a large range of CO concentrations. The empirical models of Goldsmith, Terzaghi and Hackney (1963), Ott and Mage (1978) and Venkatram and Lough (1979) take into account CO fluctuations in urban atmospheres.

Recently, models describing the physiological processes related to CO transport in the human body have presented satisfactory results. Among them the CFK model (Coburn, Forster and Kane, 1965) has been extensively used. There are several applications and validations of that model. Marcus (1980) and Collier and Goldsmith (1983) applied it in urban atmospheres.

Paper accepted April, 2008. Technical Editor: Agenor de Toledo Fleury.
The models of Selvakumar, Sharan and Singh (1992) and Sharan and Selvakumar (1999) divide the lung into compartments, one alveolar and several pulmonary capillaries. They consider, besides $\mathrm{CO}$, the exchanges of the gases $\mathrm{O}_{2}, \mathrm{CO}_{2}$ and nitrogen $\left(\mathrm{N}_{2}\right)$. Selvakumar, Sharan and Singh (1992) applied their model to high altitudes and Sharan and Selvakumar (1999) to the end-expired breath technique. The model of Bruce and Bruce (2003) also divides the human body into compartments, including the muscular and non-muscular tissues. The present model has characteristics of the lung representation of Selvakumar, Sharan and Singh (1992) and Sharan and Selvakumar (1999), and the tissue representation of Bruce and Bruce (2003).

Table 1. Effects of $\mathrm{COHb}$ level in the blood of healthy subjects [adapted from WHO(1999)].

\begin{tabular}{|c|c|}
\hline $\mathrm{COHb}(\%)$ & Effect \\
\hline$<2$ & Small decreases in work capacity \\
\hline 5 & $\begin{array}{l}\text { Decrease of oxygen uptake and exercise performance; } \\
\text { decrements in neurobehavioral function }\end{array}$ \\
\hline 10 & $\begin{array}{l}\text { Shortness of breath on vigorous exertion; possible } \\
\text { tightness across the forehead; dilation of cutaneous } \\
\text { blood vessel }\end{array}$ \\
\hline 20 & $\begin{array}{l}\text { Shortness of breath on moderate exertion; occasional } \\
\text { headache with throbbing in temples }\end{array}$ \\
\hline 30 & $\begin{array}{l}\text { Decided headache; irritable; easily fatigued; judgement } \\
\text { disturbed; possible dizziness; dimness of vision }\end{array}$ \\
\hline $40-50$ & Headache; confusion; collapse; fainting on exertion \\
\hline $60-70$ & $\begin{array}{l}\text { Unconsciousness; intermittent convulsion; respiratory } \\
\text { failure; death if exposure is long continued }\end{array}$ \\
\hline 80 & Rapidly fatal \\
\hline
\end{tabular}

The carbon monoxide transport model of the human respiratory system developed in the present work considers the exchanges of $\mathrm{CO}, \mathrm{O}_{2}$ and $\mathrm{CO}_{2}$. The human body was divided into the following compartments: alveolar, pulmonary capillaries, arterial, venous, tissue capillary, and tissues (muscular and non-muscular). The gas transport in the blood and tissues is represented by relations found in the literature. The model enables the transient distribution analysis of the gases in the human body, depending on its condition and the atmospheric air concentration. 


\section{Nomenclature}

$B E \quad=$ base excess, $\mathrm{mmol} / \mathrm{L}$

$\mathrm{COHb}=\mathrm{CO}$ hemoglobin saturation, 0 to 1

$D_{L}=$ diffusion coefficient through the respiratory membrane, $\mathrm{ml} /(\min . \mathrm{kPa})$

$F=$ fraction of gas in inspired air, 0 to 1

$[\mathrm{Hb}]=$ hemoglobin concentration, $\mathrm{g} / \mathrm{ml}$

$M=$ Haldane constant, non-dimensional

$n \quad=$ number of pulmonary capillary compartments

$\mathrm{O}_{2} \mathrm{Hb}=\mathrm{O}_{2}$ hemoglobin saturation, 0 to 1

$P \quad=$ partial pressure, $k P a$

$p H=$ blood $p H$

$Q_{B} \quad=$ cardiac output, $\mathrm{ml} / \mathrm{min}$

$R Q=$ respiratory quotient

$V \quad=$ volume, $m l$

$\dot{V}_{A} \quad=$ alveolar ventilation, $\mathrm{ml} / \mathrm{min}$

$\dot{V}_{g}=$ metabolic consumption or production rate of $g$ in the tissues, $\mathrm{ml} / \mathrm{min}$

$x \quad=$ content, $\mathrm{ml} / \mathrm{ml}$

\section{Greek Symbols}

$\alpha=$ solubility coefficient, $\mathrm{ml} /(\mathrm{ml} \mathrm{kPa})$

$\sigma \quad=$ fraction of unshunted blood, 0 to 1

\section{Subscripts}

$a \quad=$ arterial compartment

$A \quad=$ alveolar compartment

bar = barometric

$\mathrm{CO}=$ carbon monoxide

$\mathrm{CO}_{2}=$ carbon dioxide

$c p=$ pulmonary capillary compartment

ct $=$ tissue capillary compartment

$\mathrm{H}_{2} \mathrm{O}$ = water

$i \quad=$ index of the pulmonary capillary compartment, 1 to $n$

in $=$ inspired

$g \quad=$ gas $\mathrm{CO}, \mathrm{O}_{2}$ or $\mathrm{CO}_{2}$

$\mathrm{O}_{2}$ = oxygen

$p l \quad=$ plasma

$t \quad=$ tissue and tissue capillary compartment

$\mathrm{tm}=$ muscular tissues

tn $=$ non-muscular tissues

$v \quad=$ venous compartment

\section{Gases Transport}

The respiration process starts with the air passing through the dead space, where it is totally humidified. The water vapor pressure $\left(P_{\mathrm{H}_{2} \mathrm{O}}\right.$ ) at the body temperature of $37^{\circ} \mathrm{C}$ is $6.27 \mathrm{kPa}(47 \mathrm{mmHg})$.

The pressure of the inhaled gases arriving in the alveoli is the barometric pressure less the water vapor pressure.

$$
P_{g, \text { in }}=F_{g, i n}\left(P_{b a r}-P_{H_{2} O}\right)
$$

where $g=\mathrm{CO}, \mathrm{O}_{2}, \mathrm{CO}_{2} ; P_{g \text {, in }}=$ partial pressure of $g$ inspired $[\mathrm{kPa}]$; $F_{g, \text { in }}=$ fraction of $g$ in inspired air [0 to 1]; $P_{b a r}=$ barometric pressure [kPa]; $P_{\mathrm{H}_{2} \mathrm{O}}=$ water vapor pressure $[\mathrm{kPa}]$.

The gas diffusion capacity through the respiratory membrane is known in physiology by $D_{L}$. It is the relation between the flux of a gas through the respiratory membrane and its driving force, which is the difference between the alveolar partial pressure and the average of the pulmonary capillary partial pressures. It includes the diffusion through the membranes and the speed of the chemical reactions in the erythrocytes.
The $\mathrm{CO}, \mathrm{O}_{2}$ and $\mathrm{CO}_{2}$ gases are transported by the blood dissolved and chemically reacted with hemoglobin. In the tissues, they are stored dissolved. In the muscular tissues, the $\mathrm{CO}$ and $\mathrm{O}_{2}$ are also chemically reacted with myoglobin.

The amount of dissolved gases is equal to their partial pressures multiplied by the gas solubility coefficient. These coefficients for the blood at body temperature $\left(37^{\circ} \mathrm{C}\right)$ are $\left(1.7,2.2\right.$ and 50.3) $\times 10^{-4}$ $\mathrm{ml} /(\mathrm{ml} . \mathrm{kPa})$ for $\mathrm{CO}, \mathrm{O}_{2}$ and $\mathrm{CO}_{2}$ respectively. For the tissues (assumed to be the same as water), these coefficients are (1.82, 2.36 and 56) $\times 10^{-4} \mathrm{ml} /\left(\mathrm{ml} . \mathrm{kPa}\right.$ ) for $\mathrm{CO}, \mathrm{O}_{2}$ and $\mathrm{CO}_{2}$ (Altman and Dittmer, 1971).

Most of $\mathrm{O}_{2}$ is carried by the blood through its chemical reaction with hemoglobin, forming a compound called oxyhemoglobin $\left(\mathrm{O}_{2} \mathrm{Hb}\right)$. It represents the $\mathrm{O}_{2}$ hemoglobin saturation (relation between the amount of $\mathrm{O}_{2}$ reacted and the total amount of hemoglobin), where $100 \%$ corresponds to the maximum capacity of $1.34 \mathrm{ml} \mathrm{O}_{2} / \mathrm{g} \mathrm{Hb}$ (Guyton and Hall, 2006). The hemoglobin concentration in the blood $[\mathrm{Hb}]$ of a normal subject is $0.15 \mathrm{~g} \mathrm{Hb} / \mathrm{ml}$ blood (Guyton and Hall, 2006). The relation between the $\mathrm{O}_{2}$ partial pressure and its saturation is given by the dissociation curve. It varies in function of the $\mathrm{CO}_{2}$ amount in the blood and temperature. The oxygen saturation is obtained as proposed by Kelman (1966) and Thomas (1972), considering the temperature equal to $37^{\circ} \mathrm{C}$ :

$$
\begin{aligned}
& O_{2} H b=\frac{N^{4}-15 N^{3}+2045 N^{2}+2000 N}{N^{4}-15 N^{3}+2400 N^{2}-31100 N+2.4 \times 10^{6}} \\
& N=7.5 P_{O_{2}} \times 10^{[0.48(p H-7.4)-0.0013 B E]}
\end{aligned}
$$

where $\mathrm{O}_{2} \mathrm{Hb}=$ hemoglobin saturation of $\mathrm{O}_{2}$ [0 to 1]; $P_{\mathrm{O}_{2}}=$ partial pressure of $\mathrm{O}_{2}[\mathrm{kPa}] ; B E=$ base excess $[\mathrm{mmol} / \mathrm{L}]$.

The following relation represents the $\mathrm{O}_{2}$ transport in the blood.

$$
x_{\mathrm{O}_{2}}=\alpha_{\mathrm{O}_{2}} P_{\mathrm{O}_{2}}+1.34[\mathrm{Hb}] \mathrm{O}_{2} \mathrm{Hb}
$$

where $x_{O_{2}}=$ content of $\mathrm{O}_{2}[\mathrm{ml} / \mathrm{ml}] ; \alpha_{O_{2}}=$ solubility coefficient of $\mathrm{O}_{2}[\mathrm{ml} /(\mathrm{ml} . \mathrm{kPa})] ; \quad P_{\mathrm{O}_{2}}=$ partial pressure of $\mathrm{O}_{2}[\mathrm{kPa}] ;[\mathrm{Hb}]=$ hemoglobin concentration [g/ml]; $\mathrm{O}_{2} \mathrm{Hb}=$ hemoglobin saturation of $\mathrm{O}_{2}[0$ to 1$]$.

The blood carries $\mathrm{CO}$ in the same way as $\mathrm{O}_{2}$, dissolved and chemically reacted with hemoglobin. The reversible reaction of $\mathrm{CO}$ with hemoglobin forms the carboxyhemoglobin (COHb), also known as the $\mathrm{CO}$ hemoglobin saturation $(\mathrm{COHb})$. The hemoglobin affinity of $\mathrm{CO}$ is about 250 times higher than $\mathrm{O}_{2}$. The maximum blood capacity to carry reacted $\mathrm{CO}$ is the same as that of $\mathrm{O}_{2}$.

The classic work by Douglas, Haldane and Haldane (1912) is the first theoretical study of the interdependence between the $\mathrm{CO}$ and $\mathrm{O}_{2}$ hemoglobin saturation. They concluded that the presence of $\mathrm{CO}$ in the blood moves the $\mathrm{O}_{2}$ dissociation curve to the left, reduces its inclination and turns it more hyperbolic. That variation is known as the Haldane effect. Based on these observations, the theoretical relation named the Haldane equation was developed:

$$
\frac{C O H b}{O_{2} H b}=M \frac{P_{C O}}{P_{O_{2}}}
$$

where $M=$ Haldane constant.

The value of the Haldane constant $(M)$ is the hemoglobin affinity relation between $\mathrm{CO}$ and $\mathrm{O}_{2}$. Several researchers attempt to find a suitable value of this constant, being usually between 210 and 290. In the present work the value of 246, experimentally determined by Douglas, Haldane and Haldane (1912), is used. 
Figure 1 shows the $\mathrm{O}_{2}$ dissociation curve for several values of $\mathrm{COHb}$, obtained by the equations presented previously. Due to the similarity between the hemoglobin reactions of $\mathrm{CO}$ and $\mathrm{O}_{2}$, the $\mathrm{CO}$ dissociation curve in the absence of $\mathrm{O}_{2}$ has the same form of the $\mathrm{O}_{2}$ dissociation curve in the absence of $\mathrm{CO}$. The total hemoglobin saturation by $\mathrm{O}_{2}$ and $\mathrm{CO}$ is obtained by the $\mathrm{O}_{2}$ dissociation curve in the absence of $\mathrm{CO}$, considering the $P_{\mathrm{O}_{2}}$ as $P_{\mathrm{O}_{2}}+M P_{C O}$.

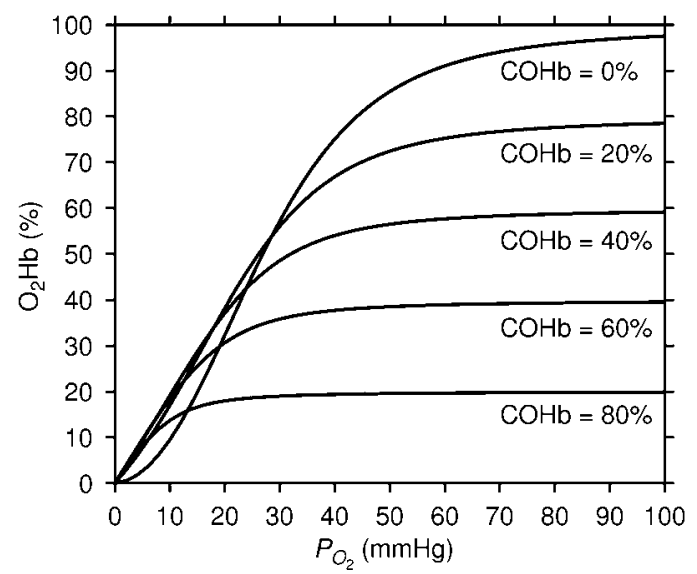

Figure 1. Dissociation curve of $\mathrm{O}_{2}$ in the blood for several values of COHb.

$\mathrm{CO}_{2}$ is transported by the blood dissolved, bonded with hemoglobin, and as bicarbonate ion. The $\mathrm{CO}_{2}$ bonded with the hemoglobin forms the carbamino $\left(\mathrm{CO}_{2} \mathrm{Hb}\right)$. However, $\mathrm{CO}_{2}$ does not occupy the same bonds with the iron atom of $\mathrm{CO}$ or $\mathrm{O}_{2}$. The amount of $\mathrm{CO}_{2} \mathrm{Hb}$ depends on the hemoglobin saturation by $\mathrm{CO}$ and $\mathrm{O}_{2}$. Most $\mathrm{CO}_{2}$ (approximately 70\%) is transported in the form of bicarbonate ion after reacting with water. To determine the total blood content of $\mathrm{CO}_{2}$, the model proposed by Douglas, Jones and Reed (1988) is used:

$$
\begin{aligned}
& x_{\mathrm{CO}_{2}}=x_{\mathrm{CO}_{2}, p l}\left[1-\frac{0.0289[\mathrm{Hb}]}{\left(3.352-0.456 \mathrm{O}_{2} \mathrm{Hb}\right)(8.142-p H)}\right] \\
& x_{\mathrm{CO}_{2}, \mathrm{pl}}=\alpha_{\mathrm{CO}_{2}} P_{\mathrm{CO}_{2}}\left[1+10^{(p H-6.1)}\right]
\end{aligned}
$$

where $x_{\mathrm{CO}_{2}, \mathrm{pl}}=$ content of $\mathrm{CO}_{2}$ in the plasma $[\mathrm{ml} / \mathrm{ml}]$.

In the tissues, the gases are stored dissolved and, in the muscular tissues, also chemically reacted. The protein called myoglobin has a function similar to that of hemoglobin in the blood. It is used for $\mathrm{O}_{2}$ storage, forming the oxymyoglobin $\left(\mathrm{O}_{2} \mathrm{Mb}\right)$. $\mathrm{CO}$ also competes with $\mathrm{O}_{2}$ for the bonds with the myoglobin, with affinity about 25 times higher, forming the carboxymyoglobin (COMb).

The maximum myoglobin capacity to store the gases is determined as the hemoglobin capacity multiplied by the relation of their molecular masses, 68000 for $\mathrm{Hb}$ and 17600 for Mb (Guyton and Hall, 2006), divided by four (hemoglobin carries four molecules and myoglobin one). That relation was based on Bruce and Bruce (2003). The myoglobin concentration in the muscles is $0.0053 \mathrm{~g} / \mathrm{ml}$ (Coburn and Mayers, 1971). The myoglobin saturation is also represented by a dissociation curve. The Hill equation was used to represent that curve, according to Schenkman et al. (1997).

The human body energy is generated by the oxidation of some compounds with bonds between carbon and hydrogen. These compounds are the carbohydrates, fats and some carbon-hydrogen chains. $\mathrm{CO}_{2}$ and water are generated as a product of that oxidation. This process is known as metabolism. The relationship between the amount of $\mathrm{CO}_{2}$ produced and the $\mathrm{O}_{2}$ consumed is the respiratory quotient $(R Q)$.

The human body produces $\mathrm{CO}$ in an endogenous way, mainly in the process of hemoglobin degradation (about 80\%). The organ responsible for producing most $\mathrm{CO}$ is the liver. Coburn, Blakemore and Forster (1963) experimentally determined the value of CO endogenous production in rest as $0.007 \mathrm{ml} / \mathrm{min}$.

The blood is distributed in the body by the cardiac output $\left(Q_{B}\right)$. Through the lung, only a fraction of the cardiac output exchange gases with the alveoli. That fraction, known by $\sigma$, is equal to 0.98 for a normal person (Guyton and Hall, 2006).

The total blood volume in the human body of adults is approximately $5000 \mathrm{ml}$ (Guyton and Hall, 2006). That volume is divided in four parts. One represents the blood in the pulmonary capillary, with volume $\left(V_{c p}\right)$ equal to $100 \mathrm{ml}$ (Mountcastle, 1980). The others values, based on Guyton and Hall (2006), are the arterial blood $\left(V_{a}\right)$, equal to $1000 \mathrm{ml}$, the venous blood $\left(V_{v}\right)$, equal to 3550 $\mathrm{ml}$, and the blood present in the tissues capillary $\left(V_{c t}\right)$, equal to 350 $\mathrm{ml}$.

The volume of muscular tissues $\left(V_{t m}\right)$ is approximately 30000 $\mathrm{ml}$. The volume of the non-muscular tissues $\left(V_{t n}\right)$ is approximately $7000 \mathrm{ml}$, determined by the volume of water ( $60 \%$ of body weight) less the volume of the muscular tissues and blood. The alveolar volume $\left(V_{A}\right)$ is approximately $2000 \mathrm{ml}$ in the end of expiration (Mountcastle, 1980).

The present model considers the variations of the physiologic parameters that more significantly affect the respiratory process, related to the $\mathrm{O}_{2}$ consumption $\left(\dot{V}_{O_{2}}\right)$. These parameters are the alveolar ventilation ( $\left.\dot{V}_{A}\right)$, cardiac output $\left(Q_{B}\right)$, diffusion capacities $\left(D_{L}\right)$, and respiratory quotient $(R Q)$. Experimental data from several authors were used to linearly interpolate an equation for each parameter. The equations define the parameter equal to $a+b \dot{V}_{O_{2}}$. The values of the coefficients $a$ and $b$ are presented in Tab. 2 .

Table 2. Interpolated parameters (Parameter $\left.=\mathbf{a}+\mathbf{b} \dot{\mathrm{V}}_{\mathrm{O}_{2}}\right)$.

\begin{tabular}{lcccr}
\hline Parameter & $a$ & $b$ & Unit & Reference \\
\hline$\dot{V}_{A}$ & -99.7 & 17.55 & $\mathrm{ml} / \mathrm{min}$ & Guyton and Hall (2006) \\
$Q_{B}$ & 3738 & 7.6 & $\mathrm{ml} / \mathrm{min}$ & Guyton and Hall (2006) \\
$D_{L, O_{2}}$ & 153 & 0.287 & $\mathrm{ml} /(\mathrm{min} . \mathrm{kPa})$ & Turrino et al. (1963) \\
$D_{L, C O_{2}}$ & 456 & 1.25 & $\mathrm{ml} /(\mathrm{min} . \mathrm{kPa})$ & Piiper et al. (1980) \\
$D_{L, C O}$ & 187 & 0.15 & $\mathrm{ml} /(\mathrm{min} . \mathrm{kPa})$ & Turrino et al. (1963) \\
$R Q$ & 0.826 & 0.0000985 & - & Turrino et al. (1963) \\
\hline
\end{tabular}

Four physical activities were considered: resting, sitting, standing and walking. The values of $\dot{V}_{\mathrm{O}_{2}}$ for each activity are 245, 346, 513 and $1020 \mathrm{ml} / \mathrm{min}$, respectively (Mountcastle, 1980).

\section{Model Presentation}

The method used to represent the respiratory system is the division of the human body reservoirs of blood, gases and tissues into compartments. The model is formed by five compartments, besides some representing the pulmonary capillaries (Fig. 2). 


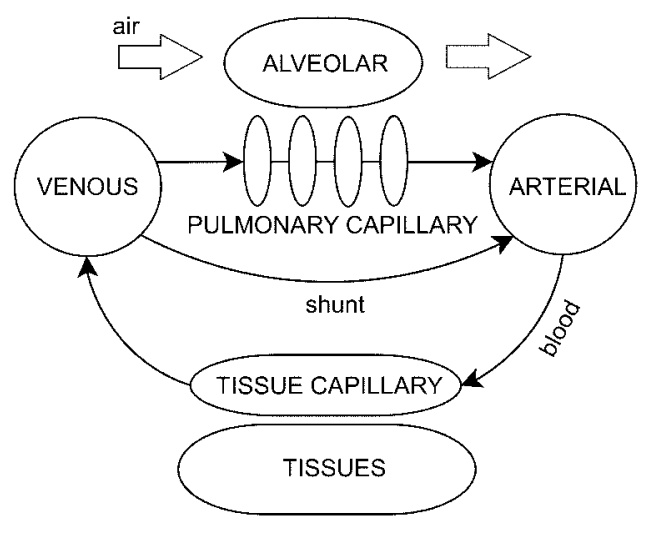

Figure 2. Model representation.

For the model equation development, principles of mass conservation were used. The gases and liquids inside the compartments are considered uniform. The gas composition in each compartment is described by ordinary differential equations representing the time variation, one for each compartment and one for each gas. The sub-index $g$ represents each one of the gases, being $g$ equal to $\mathrm{CO}, \mathrm{O}_{2}$ or $\mathrm{CO}_{2}$.

\section{Alveolar Compartment}

The first compartment, which connects the human body to the external air, is the alveolar compartment. It represents the gas found in the lung alveoli. The flow through that compartment is the alveolar ventilation. Inspired air gets in after being humidified in the dead space. Another important process in the alveolar compartment is the gas transfer by diffusion with the pulmonary capillary compartments through the respiratory membrane. The following equation represents the overall process, with the diffusion coefficient correction from STPD (Standard Temperature and Pressure Dry) to BTPS (Body Temperature and Pressure Saturated) (Altman and Dittmer, 1971):

$V_{A} \frac{d P_{g, A}}{d t}=\dot{V}_{A}\left(P_{g, i n}-P_{g, A}\right)-\frac{310}{273} 101.325 \frac{D_{L, g}}{n} \sum_{i=1}^{n}\left(P_{g, A}-P_{g, c p(i)}\right)$

where $V_{A}=$ volume of the alveolar compartment [ml]; $P_{g, A}=$ partial pressure of $g$ in the alveolar compartment [kPa]; $\dot{V}_{A}=$ alveolar ventilation $[\mathrm{ml} / \mathrm{min}] ; D_{L, g}=$ diffusion coefficient of $g$ through the respiratory membrane $[\mathrm{ml} /(\min . \mathrm{kPa})] ; i=$ index of the pulmonary capillary compartment [1 to $n$ ]; $n=$ number of pulmonary capillary compartments; $P_{g, c p(i)}=$ partial pressure of $g$ in the pulmonary capillary compartment $i[\mathrm{kPa}]$.

\section{Pulmonary Capillary Compartment}

The pulmonary capillaries are represented by a series of compartments. Unshunted blood flows through them. Venous blood enters the first compartment. Then the blood flows to the next pulmonary capillary compartment exchanging gases with the alveolar compartment through the respiratory membrane. The diffusion coefficient is considered constant in all compartments.

The reason of using several compartments is the need of an adquate value of the local driving force since the gases change their concentration as they flow in the capillaries. Considering the computational effort and the need of a smooth curve, 10 compartments were considered enough. The following equation represents the gas content variation of each pulmonary capillary compartment:

$$
\frac{V_{c p}}{n} \frac{d x_{g, c p(i)}}{d t}=Q_{B} \sigma\left(x_{g, c p(i-1)}-x_{g, c p(i)}\right)+\frac{D_{L, g}}{n}\left(P_{g, A}-P_{g, c p(i)}\right)
$$

where $V_{c p}=$ volume of all pulmonary capillary compartments [ml]; $x_{g, c p(i)}=$ content of $g$ in the pulmonary capillary compartment $i$ $[\mathrm{ml} / \mathrm{ml}] ; Q_{B}=$ cardiac output $[\mathrm{ml} / \mathrm{min}] ; \sigma=$ fraction of unshunted blood.

\section{Arterial Compartment}

The unshunted blood that leaves the pulmonary capillaries mixes with the shunted blood and follows to the arterial compartment. It works as a system time delay. The following equation represents the arterial content variation:

$$
V_{a} \frac{d x_{g, a}}{d t}=Q_{B}\left[\sigma x_{g, c p(n)}+(1-\sigma) x_{g, v}-x_{g, a}\right]
$$

where $V_{a}=$ volume of the arterial compartment [ml]; $x_{g, a}=$ content of $g$ in the arterial compartment $[\mathrm{ml} / \mathrm{ml}] ; x_{g, v}=$ content of $g$ in the venous compartment $[\mathrm{ml} / \mathrm{ml}]$.

\section{Tissue and Tissue Capillary Compartments}

The next compartment in which the blood flows is the tissue capillary compartment. There the blood exchanges gases with the tissue compartment, where metabolism takes place. The mechanism of tissue diffusion is complex. Because of that, it was simplified in the present model considering the gas partial pressures in the tissue capillary the same as the tissues.

The tissue compartment is divided in two volumes, one representing the non-muscular tissues and another representing the muscular tissues, where the gases $\mathrm{CO}$ and $\mathrm{O}_{2}$ are bonded to myoglobin. In the tissues, the $\mathrm{O}_{2}$ is consumed $\left(\dot{V}_{\mathrm{O}_{2}}\right)$ and the gases $\mathrm{CO}$ and $\mathrm{CO}_{2}$ are produced with rates $\dot{V}_{\mathrm{CO}}$ and $\dot{V}_{\mathrm{CO}_{2}}$, respectively.

The partial pressure variation of both compartments is represented by the following equation:

$$
\left(V_{c t} \frac{d x_{g, c t}}{d P_{g, t}}+V_{t m} \frac{d x_{g, t m}}{d P_{g, t}}+V_{t n} \frac{d x_{g, t n}}{d P_{g, t}}\right) \frac{d P_{g, t}}{d t}=Q_{B}\left(x_{g, a}-x_{g, c t}\right)-\dot{V}_{g}
$$

where $V_{c t}=$ volume of the tissue capillary compartment [ml]; $x_{g, c t}=$ content of $g$ in the tissue capillary compartment $[\mathrm{ml} / \mathrm{ml}] ; P_{g, t}=$ partial pressure of $g$ in the tissue and tissue capillary compartment $[\mathrm{kPa}] ; V_{t m}=$ volume of the muscular tissues [ml]; $x_{g, t m}=$ content of $g$ in the muscular tissues $[\mathrm{ml} / \mathrm{ml}] ; V_{t n}=$ volume of the non-muscular tissue [ml]; $x_{g, t n}=$ content of $g$ in the non-muscular tissues $[\mathrm{ml} / \mathrm{ml}]$; $\dot{V}_{g}=$ metabolic consumption or production rate in the tissues $[\mathrm{ml} / \mathrm{min}]$.

\section{Venous Compartment}

After the tissue capillary compartment, the blood follows to the venous compartment. Leaving it, the blood returns to the lung. The venous compartment also works as a system time delay. The following equation represents the venous content variation: 


$$
V_{v} \frac{d x_{g, v}}{d t}=Q_{B}\left(x_{g, c t}-x_{g, v}\right)
$$

where $V_{v}=$ volume of the venous compartment [ml].

\section{Numerical Solution}

A computational program based on $\mathrm{C}++$ language was developed in order to solve the equations in the steady state and transient conditions. The steady state solution is necessary to define the subject conditions in the beginning of the simulation. The conservation equations were solved using the successive approximation method for the steady state solution and the explicit Euler integration method for the transient solution.

\section{Results}

\section{Validation}

Stewart et al. (1970) conducted experiments exposing several subjects to CO concentrations of 50, 100, 200, 500 and 1000 ppm for periods from half hour to twenty-four hours. The COHb was obtained by the analysis of venous blood samples along the experiment. The post-exposition was also measured, breathing pure air. These data were used to validate the model. Figure 3a, Fig. 3b and Fig. 3c present the experimental data $(\bullet)$ and the numerical simulation (-) for constant CO concentrations of 50, 100 and 200 ppm respectively. Figure 3d presents the validation for a constant exposition of $500 \mathrm{ppm}$ and an exposition with the $\mathrm{CO}$ concentration being incremented from 0 to $1000 \mathrm{ppm}$.

It was considered a typical subject, male, with $70 \mathrm{~kg}$ weight, $1.74 \mathrm{~m}$ height, and 30 years old at sea level with light levels of physical activity, depending on the exposition time. For the 50 and $100 \mathrm{ppm}$ expositions the sitting activity was considered. For the 200, 500 and 1000 ppm exposition the activity was considered to be an average between sitting and standing. The initial condition was adjusted according to each experiment data.

The numerical results agree very well with the experimental data. For the post-exposition period, the agreement is also good.

\section{Urban Atmosphere}

The carbon monoxide concentration curves for critical days of the urban atmosphere of São Caetano do Sul (metropolitan area of São Paulo, SP, Brazil) were selected for simulation. On these days, in the year of 2003, the CO concentration presented great variations (Fig. 4). The time axis begins at 8:00 AM of July 19th and ends at 4:00 PM of July 23rd. The peaks of CO concentration occurred between 1:00 AM and 6:00 AM. The hourly concentration data were obtained from the local environmental protection agency (CETESB, 2004). These data were used as model input.

\section{Physical Activity}

Figure 5 represents the $\mathrm{COHb}$ variation in the venous blood for four different levels of physical activity. It was considered a typical subject, male, with $70 \mathrm{~kg}$ weight, $1.74 \mathrm{~m}$ height, and 30 years old at sea level. As the physical activity level increases, the intensity of $\mathrm{CO}$ uptake and elimination also increase. The highest physical activity level simulated was an individual walking, presenting the highest and the lowest COHb levels. The more intense the physical activity, the more critical becomes the $\mathrm{CO}$ intoxication.

\section{Air Quality Criteria}

"Quality air criteria are concentrations of atmospheric pollutants that, once exceeded, can affect the health, safety, and wellness of the population, as well as cause damage to the flora and fauna, to the materials and to the ecosystem in general" (CONAMA, 1990). In the case of $\mathrm{CO}$, it is defined based on the COHb limit in which humans do not suffer damages from poisoning. The Environmental Protection Agency (EPA, 2000) defined this limit as 2\% of COHb in the blood, from several studies in men and animals. They are expressed as limits of average CO concentration that should not be exceeded more than once a year. The average concentration on an eight-hour exposition can not exceed $9 \mathrm{ppm}$, and on an one-hour exposition can not exceed 35 ppm (EPA, 2000; CONAMA, 1990). These definitions are used in several countries.

There are some studies about the validity of the CO quality air criteria using mathematical models. The analysis of Ott and Mage (1978) and Venkatram and Lough (1979) with empirical models suggested that the eight-hour criterion does not take into account peaks of variation. Ott and Mage (1978) proposed the use of a shorter average time as criteria and Venkatram and Lough (1979) suggested the use of a biological model. Collier and Goldsmith (1983) and Selvakumar, Sharan and Singh (1992) tested the criteria in high altitudes and concluded that volumetric standards are more appropriate than gravimetric standards.

Aiming at comparing the present model results with the eighthour quality air criterion, the eight-hour average of the input data (Fig. 4) and the $\mathrm{COHb}$ concentration from the walking subject (Fig. 5) are plotted together in Fig. 6. The two ordinate axes represent $\mathrm{COHb}$ level (left) and CO concentration (right). To plot this figure, two assumptions were made. The first is that the $9 \mathrm{ppm}$ limit for the eight-hour average is equivalent to the $2 \% \mathrm{COHb}$ limit concentration. The second assumption is that, in the absence of CO in the air (concentration of $0 \mathrm{ppm}$ ), the $\mathrm{COHb}$ level in the blood is equal to $0.5 \%$, representing the CO produced by the human body. The simulation result is very close to the eight-hour average, mainly for high CO concentrations.

That result suggests that, for a typical subject, the use of the eight-hour average as CO quality air criterion is valid for light and moderate physical activity levels. On the other hand, it is noteworthy that the safety threshold of each subject may vary upon several characteristics not considered in the present model such as age, co-morbidities and genetic polymorphisms.

\section{Conclusions}

In the present work, a $\mathrm{CO}$ transport model for the human respiratory system was developed, considering the exchanges of $\mathrm{CO}, \mathrm{O}_{2}$ and $\mathrm{CO}_{2}$. The human body was divided in compartments, representing the places where these gases are present (alveolar, several pulmonary capillaries, arterial, venous, tissue capillary and tissues). The mathematical modeling generated a set of equations describing the gases transient concentration in each compartment, in function of physiological parameters. The model validation was done by comparing its results with experimental data. The agreement was good.

After validating the model, it was applied for some situations in urban atmospheres. The first result is about physical activity. Four conditions were simulated (resting, sitting, standing and walking). It was concluded that high physical activity levels present greater variations in the $\mathrm{COHb}$ level, being more susceptible to intoxication.

The last analysis was about the $\mathrm{CO}$ air quality criterion, which says that the average CO concentration of eight hours cannot exceed $9 \mathrm{ppm}$. The curve of these average is very close to the COHb curve of a walking typical subject. 

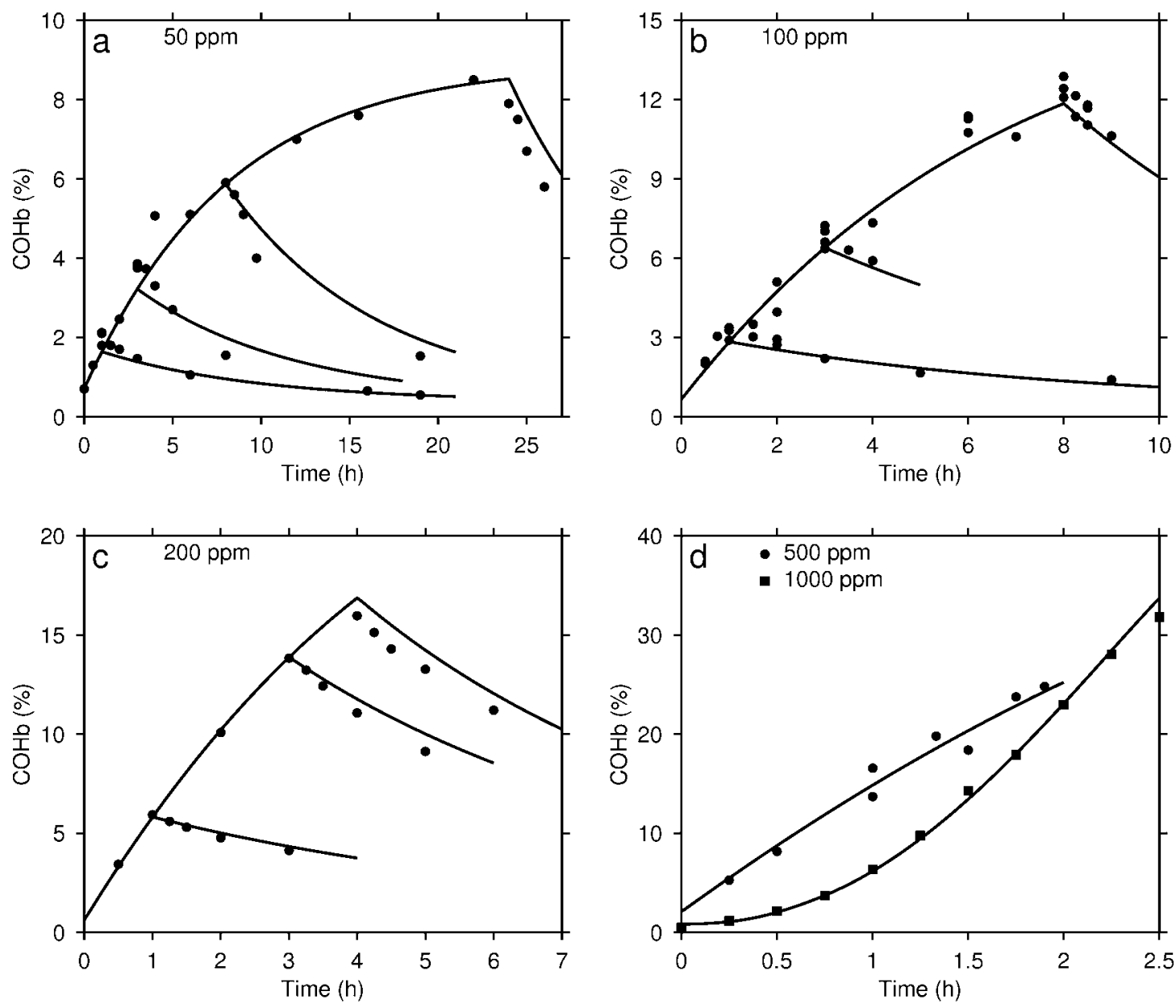

Figure 3. Comparison of $\mathrm{COHb}$ levels from the present model (-) and the experimental data (-) from Stewart et al. (1970) for CO concentrations of (a) 50 ppm, (b) 100 ppm, (c) 200 ppm, (d) 500 and 1000 ppm.

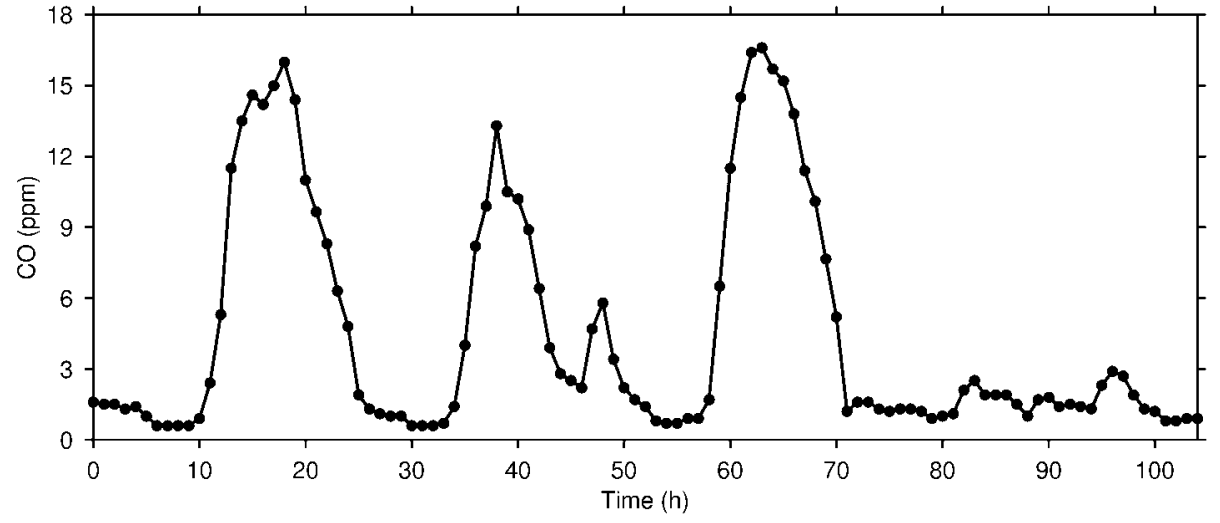

Figure 4. CO concentration in São Caetano do Sul from 2003 8:00 AM July 19th to 4:00 PM July 23rd (simulation input data). 


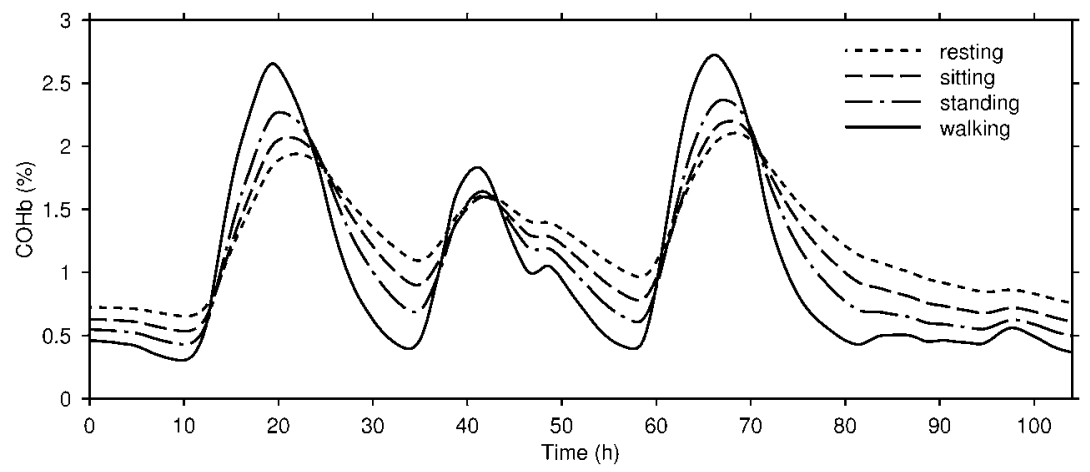

Figure 5. COHb for several physical activity levels.

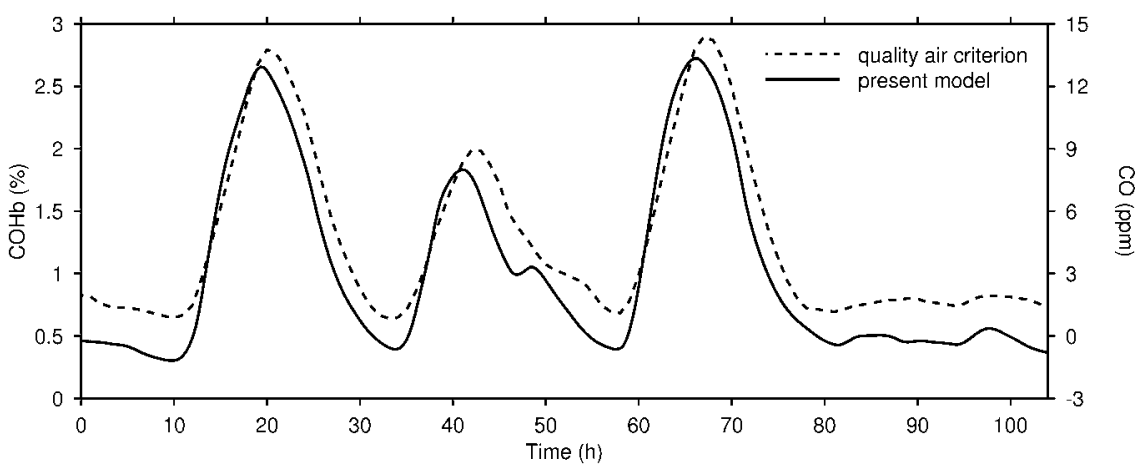

Figure 6. Comparing the present model with the CO eight-hour average air quality criterion.

\section{References}

Altman, P.L. and Dittmer, D.S., 1971, "Respiration and circulation. Biological Handbooks", Federation of American Societies for Experimental Biology, Bethesda, United States of America, 930 p.

Bruce, E.N. and Bruce, M.C., 2003, "A multicompartment model of carboxyhemoglobin and carboxymyoglobin responses to inhalation of carbon monoxide", Journal of Applied Physiology, Vol.95, pp. 1235-1247.

CETESB - Company of Environmental Sanitation Technology, 2004, "Hourly data of carbon monoxide (CO) in the Metropolitan Region of São Paulo and Countryside - 2003" (In Portuguese), S.Paulo, Brazil, 155 p.

Coburn, R.F., Blakemore, W.S. and Forster, R.E., 1963, "Endogenous carbon monoxide production in man", Journal of Clinical Investigation, Vol.42, pp. 1172-1178.

Coburn, R.F., Foster, R.E. and Kane, P.B., 1965, "Considerations of the physiological variables that determine the blood carboxyhemoglobin concentrations in man”, Journal of Clinical Investigation, Vol.44, pp. 18991910.

Coburn, R.F. and Mayers, L.B., 1971, "Myoglobin O tension determined from measurements of carboxymyoglobin in skeletal muscle", American Journal of Physiology, Vol.220, pp. 66-74.

Collier, C.R. and Goldsmith, J.R., 1983, "Interactions of carbon monoxide and hemoglobin at high altitude", Atmospheric Environment, Vol.17, pp. 723-728.

CONAMA - National Environmental Council, 1990, "Resolution n.3 of July 28th 1990” (In Portuguese), Brazil.
Douglas, C.G., Haldane, J.S. and Haldane, J.B.S., 1912, "The laws of combination of Hæmoglobin with carbon monoxide and oxygen”. Journal of Physiology, Vol.44, pp. 275-304.

Douglas, A.R., Jones, N.L. and Reed, J.W., 1988, "Calculation of whole blood CO content”, Journal of Applied Physiology, Vol.65, pp. 473-477.

EPA - Environmental Protection Agency, 2000, "Air Quality Criteria for Carbon Monoxide”, EPA 600/P-99/001F, 2.ed, Washington, United States of America, $295 \mathrm{p}$.

Forbes, W.H., Sargent, F. and Roughton, F.J.W., 1945, "The rate of carbon monoxide uptake by normal men", American Journal of Physiology, Vol.143, pp. 594-608.

Goldsmith, J.R., Terzaghi, J. and Hackney, J.D., 1963, "Evaluation of fluctuating carbon monoxide exposures”, Archives of Environmental Health, Vol.7, pp. 647-663.

Guyton, A.C. and Hall, J.E., 2006, "Textbook of medical physiology”, 11.ed, Ed. Saunders, Philadelphia, United States of America, 1116 p.

Kelman, G.R., 1966, "Digital computer subroutine for the conversion of oxygen tension into saturation”, Journal of Applied Physiology, Vol.21, pp. 1375-1376.

Lilienthal, J.L. and Pine, M.B., 1946, "The effect of oxygen pressure on the uptake of carbon monoxide by man at sea level and at altitude", American Journal of Physiology, Vol.145, pp. 346-350.

Marcus, A.H., 1980, "Mathematical models for carboxyhemoglobin", Atmospheric Environment, Vol.14, pp. 841-844.

Mountcastle, V.B., 1980, “Medical physiology”, 14.ed, Ed. C.V. Mosby Company, St. Louis, United States of America, $1999 \mathrm{p}$.

Ott, W.R. and Mage, D.T., 1978, "Interpreting urban carbon monoxide concentrations by means of a computarized blood COHb model”, Journal of the Air Pollution Control Association, Vol.28, pp. 911-916. 
Pace, N., Consolazio, W.V., White, W.A. and Behnke, A.R., 1946, "Formulation of the principal factors affecting the rate of uptake of carbon monoxide by man”, American Journal of Physiology, Vol.147, pp. 352-359.

Peterson, J.E. and Stewart, R.D., 1970, "Absorption and elimination of carbon monoxide by inactive young men”, Archives of Environmental Health, Vol.21, pp. 165-171.

Piiper, J., Meyer, M., Marconi, C. and Scheid, P., 1980, "Alveolarcapillary equilibration of $\mathrm{CO}$ in human lungs studied by rebreathing”, Respiration Physiology, Vol.42, pp. 29-41.

Schenkman, K.A., Marble, D.R., Burns, D.H. and Feigl, E.O., 1997, "Myoglobin oxygen dissociation by multiwavelenght spectroscopy", Journal of Applied Physiology, Vol.82, pp. 86-92.

Selvakumar, S., Sharan, M. and Singh, M.P., 1992, "Mathematical model for the exchange of gases in the lungs with special reference to carbon monoxide”, Medical \& Biological Engineering \& Computing, Vol.30, pp. 525-532.

Sharan, M. and Selvakumar, S., 1999, "A mathematical model for the simultaneous transport of gases to compute blood carboxyhaemoglobin build-up due to CO exposures: application to the end-expired breath technique”, Environmental Pollution, Vol.105, pp. 231-242.

Stewart, R.D., Peterson, J.E., Baretta, E.D., Bachand, R.T., Hosko, M.J. and Herrmann, A.A., 1970, "Experimental human exposure to carbon monoxide”, Archives of Environmental Health, Vol.21, pp. 154-164.

Stewart, R.D., Peterson, J.E., Fischer, T.N., Hosko, M.J., Dodd, H.C. and Herrmann, A.A., 1973, "Experimental human exposure to high concentrations of carbon monoxide", Archives of Environmental Health, Vol.26, pp. 1-7.

Thomas, L.J., 1972, “Algorithms for selected blood acid-base and blood gas calculations”, Journal of Applied Physiology, Vol.33, pp. 154-158.

Turrino, G.M., Bergofsky, E.H., Goldring, R.M. and Fishman, A.P., 1963, "Effect of exercise on pulmonary capacity", Journal of Applied Physiology, Vol.18, pp. 447-456.

Venkatram, A. and Lough, R., 1979, "Evaluation of CO quality criteria using a COHb model”, Atmospheric Environment, Vol.13, pp. 869-872.

WHO - World Health Organization, 1999, "Carbon monoxide", Environmental Health Criteria 213, 2.ed, Geneva, Switzerland, 492 p. 